ISSN 2078-6441. Вісник Львівського університету. Серія географічна. 2014. Випуск 47. С. 301-305. Visnyk of the Lviv University. Series Geography. 2014. Issue 47. P. 301-305.

910 (477):001.8

\author{
вло тойко \\ ьвівський н ціон льний університет імені в н \\ вул. . орошенк, 41, 79000, м. ввів, кр їн
}

озглянуто періодиз цію ет пу ст новлення новітньої укр їнської геогр фії як синтезув льний чинник н уки. ї поворотними момент ми є тем тичний н ліз пр ць, особливості методології, перев жні підходи, принципи тощо. н лізі цього процесу вр хов но з г льну схему філософського, історичного т геогр фічного підходів. виділенні кожного з періодів в жливим є виявлення зв'язків поєдн ння і водноч с виокремлення відмінностей між ними (історикокомп р тивістський, структурно-генетичний т інші підходи).

ет пі ст новлення новітньої укр їнської геогр фії виділено три періоди: 1) гум ніт рноемпіричний (з родження, 3 другої половини ст. до 1905 р.); 2) природозн вчо-уз г льнюв льний (з 1905 р. до 20-х років ст., формув лися перші ф хові теоретичні з с ди (концепти) й уз г льнення); 3) теоретичний (теоретично-прикл дний, охоплює період від 20-30-х до середини 50-х років ст., скл лися головні теоретичні позиції професійної н уки й освіти геогр фів). продовж цих періодів у геогр фії змінюв ли одн одну декільк п нівних п р дигм (хорологічн , компонентн , комплексн ).

лючові слов : ст новлення і періодиз ція геогр фії, методологічні підходи, геогр фічн тем тик .

ш мет - виявити т про н лізув ти основні періоди ст новлення новітньої укр їнської геогр фії, їхні тем тичні й проблем тичні зміни.

ропонов н тем опр цьов н в невеликій кількості пр ць [2, 4]. сновні спекти цієї теми стосовно укр їнської геогр фії висвітлені в пр цях геогр фів ост ннього ч су - . блія [7], . енисик [1], . лійник [6], . уп нського [3].

тосовно методологічних підходів у визн ченні періодиз ції, то вони інколи є предметом спеці льного дослідження, одн к це швидше виняток, ніж пр вило. підст ві з г льних міркув нь можемо стверджув ти, що періодиз ція історії н уки з г лом т історії геогр фії зокрем є методологічною проблемою, в жливим пит нням історії і теорії геогр фії [5]. ут в гомий момент - орг нічне поєдн ння історії геогр фії з ії періодиз цією, яку можн розпоч ти з умови н явності дост тньої кількості м тері лів, отже, вон є синтезув льним чинником н уки, їі підсумком і не лише уз г льненням історії н уки, її предмет й з вд нь, й з'ясув нням їі сутності.

еріодиз ція д $є$ змогу виокремити ет пи дослідження н підст ві окремих періодів розвитку історії геогр фії як окремої г лузі зн нь. р зі іiі виділення необхідно вр хув ти з г льну схему історичного, геогр фічного т філософського процесу. снує з г льн періодиз ція розвитку н уки, н тлі якої виділяється історія геогр фії і, вл сне, особливості їі розвитку слугують предметною основою у вирішенні цієї проблеми.

еріодиз ція повинн віддзерк люв ти основні здобутки н уки, п нівні концепції чи п р дигми, головні н прями їі розвитку.

(C) тойко ., 2014 
оворотні моменти систем тиз ції н уки - тем тичні і, відповідно, проблем тичні зміни, нові інтерпрет ції с мої н уки т ї̈ структури, методологічні підходи використовув них зр зків. инуле з вжди вивч ємо 3 окремими д ними (окремою тем тикою), до того ж, суч сний ст н розвитку н уки ніби “проектує” тем тику, 3 якою іiї потрбно вивч ти. міру розвитку н уки розвив ється іï проблем тик .

еріодиз ція історії геогр фії може не збіг тися, н прикл д, із з г льноісторичною періодиз цією. виділенні ет пів історії геогр фії в жливо виявити зв'язки поєдн ння і водноч с виокремлення відмінностей між ними бо ж вплив окремих чинників н іiї розвиток.

ожен ет п (i, відповідно, період) розвитку н уки пов'яз ний з попереднім, використовує результ ти нових методологічних підходів щодо пошуку і появи конструктивних геогр фічних ідей, в жливих з погляду суч сності. сторіогр фічний підхід допом гє упорядкув ти джерелозн вчі пр ці, звести їх у систему, як д $є$ уз г льнено цілісну к ртину. систему можн вибудув ти, використовуючи з г льнофілософські (н прикл д, гносеологічний, ксіологічний) т з г льнон укові (структурно-системні) підходи. жливе зн чення у вибудові цілісної к ртини м $\epsilon$ методологія історії геогр фії (історико-комп р тивістський т структурно-генетичний підходи). озподіл джерел послугув в підгрунтям для розробки основ періодиз ції розвитку історії геогр фії як скл дової історіогр фічного вивчення.

иділені нижче періоди того чи іншого ет пу історії укр їнської геогр фії є поч тковими, недост тньо вивченими й обгрунтов ними, хоч $і$ їхня н явність грунтується н процес х, виокремлених у суспільному житті кр їни кінця половини ст. цьому контексті до ув ги н с мперед необхідно бр ти тем тичний н ліз пр ць (проблем тику), особливості методології і тих підходів (принципів), що домінують у тому чи іншому періоді. од мо, що в другій половині -н поч тку

ст. в історії геогр фії кр їни змінюв лося бо існув ло кільк п р дигм з відмінними принцип ми підходів у н укових дослідженнях, отже, і в теоретичних уз г льненнях. е в рто випуск ти з поля зору розуміння того, у яких конкретноісторичних умов х відбув лося ст новлення укр їнської геогр фії, які к федри, школи, пост ті формув ли н прями т історію геогр фічної н уки, як відбув лося усп дкув ння н укових зн нь, які н прями з лиш лися пріоритетними, які й не розвив лися вз г лі [7].

о ж стосується методологічних підходів до періодиз ції ст новлення новітньої укр їнської геогр фії, то їх (з незн чною кількістю пр ць) пр ктично не вивч ли. ожен з періодів м є якісну х р ктеристику розвитку н уки. історії розвитку геогр фії виділяють ет п ст новлення і розвитку історії укр їнської геогр фії з т кими період ми: перший - гум ніт рно-емпіричний (з родження) з другої половини ст. до 1905 р.; другий - природозн вчо-уз г льнюв льний з 1905 р. до 20-х років ст., коли формув лись перші ф хові теоретичні з с ди (концепти) й уз г льнення; третій теоретичний (теоретично-прикл дний), охоплює період від 20-30-х до середини 50-х років ст. цей період скл лися головні теоретичні позиції професійної н уки й освіти геогр фів.

ирішення пит ння періодиз ції ет пу ст новлення новітньої укр їнської геогр фії н штовхується н недост тню обгрунтов ність і відсутність дет льної опр цьов ності окремих їі періодів.

продовж з зн чених періодів - кінця -середини ст. - у геогр фії змінили одн одну декільк п р дигм. ожн 3 них н ділен теоретико-методологічними 
підход ми, специфічними здобутк ми н уки як результ том окремого періоду. жливим є висвітлення способу й умов отрим ння нових результ тів.

ожен період того чи іншого ет пу відрізняється особливостями в оцінці підходів до вивчення історії геогр фії щодо зібр ного і н пр цьов ного м тері лу. прикл д, н прикінці ст. розвиток геогр фії супроводжув вся поступовим впров дженням геогр фії у вищі з кл ди, отже, відбув лось ф хове осмислення мети, з вд ння і предмет, методів і н прямів вивчення основних проблем і геогр фічних поглядів окремих діячів. г лом, зрозуміло, з г льнон укових і уз г льнюв льних пр ць було обм ль. поч тковий період вивч ли ст н впров дження геогр фії. другій половині

ст. її досліджув ли в меж х з г льних процесів розвитку освіти в осійській т встро- горській імперіях.

руг половин ст.-1905 р.є поч тковим періодом ет пу ст новлення новітньої укр їнської геогр фії. той ч с геогр фія поступово поверт л ся н природничі з с ди розвитку і з кріплюв л ся в меж х вищих н укових 3 кл дів. ї депти, перев жно учителі, розробляли з с ди геогр фії як єдиної системи н укових зн нь. більшення кількості дослідників історії геогр фії того періоду привело до обміну теоретикометодологічних поглядів вид тних геогр фів, вони, відповідно, втягнули в предметне поле різном нітні джерел, ф кти, явищ. ем тик геогр фічних досліджень не з вжди пов'яз н з предметом і методом геогр фії.

т п ст новлення новітньої укр їнської геогр фії був н дзвич йно в жливим. ін визн чив нові з с ди порівняно з тими, до яких н той ч с примик л гегр фія. т новлення геогр фії розпоч лося в ч си зміни н укової п р дигми з хорологічної н компонентну (геокомпонентну).

1905 р. з'явил ся зН чн кількість різном нітних тем тичних підходів, ктивізув вся укр їнський н ціон льний рух. ДН К 3 Зн чимо, що в цей період розвитку геогр фічної н уки ще був не до кінця визн чений ії̈ предмет, метод, зміст, т водноч с з'явилися перші уз г льнюв льні пр ці. еогр фи докл д ли зусилля для дослідження явищ i процесів 3 позиції перев жної методології, н прикл д, еволюціонізму.

ля другого періоду ст новлення новітньої укр їнської геогр фії х р ктерний зн чний доробок, що охоплює здобутки ершої світової війни (військової геогр фії, к ртогр фії, політичної геогр фії, природничої т нтропогеогр фії), пошуки нових підходів і опр цюв ння м тері лів, зумовлених зн чними змін ми. прикл д, у 1917-1918 рок х з вершил ся ерш світов війн, зросл н ціон льн свідомість і розпоч л ся боротьб з кр їнську держ ву. ьому періоду прит м нні скл дні внутрішні процеси тр нсформ ції проблем тики геогр фії кр їн, пошуки вирішення проблеми н ціон льної школи. озвиток геогр фічної н уки відбув вся н кону пожв влення суспільно-політичного життя. кл дено основи укр їнської держ вності і нової укр їнської школи - світоглядні позиції . p нк , . рушевського, . гієнк т ін.; у геогр фії - . удницького, . утковського, . инявського, . ольницького, . еринович , . довського, . теп нів, . убійович т ін. е сприяло появі великої кількості джерел, різнобічних тем тичних досліджень, що свідчить про якісні зміни в підход х до їхнього н лізу. 1920-х рок х, 3 утвердженням більшовицької вл ди в кр їні, у геогр фію вкорінил ся м рксистськ методологія.

г лом цей період був суперечливим і скл дним, що пояснюють спробою утвердження укр їнської нез лежності (1917-1920), утворенням кр їнської н родної республіки, політикою укр їніз ції і появою пр ць геогр фів у системі дисциплін 
укр їністики. цік вленість геогр фією дед лі більше зрост л, розвив лися нові н прями в геогр фії, обгрунтовув ли, з одного боку, необхідність демокр тиз ціз ції освіти, 3 іншого - осл блюв ли, бо з лиш ли поз ув гою, н прикл д, пит ння розвитку політичної геогр фії т к ртогр фії, звужув лося коло поз політичного розвитку методологій. е був період інтенсивної міжн родної співпр ці і водноч с емігр ції зн чної ч стини н укових пр цівників.

1920-х рок х з'явилися пр ці з геогр фії, шкільної геогр фії, к ртогр фії, яким поступово н кид ли п ртійні вимоги, гребув ли об'єктивним б ченням, різнобічним н лізом т оцінкою геогр фічних досліджень.

ретій період (кінець 20-поч ток 30-х років - середин ст.) пов'яз ний зі ст новленням т розвитком історії геогр фії н з с д х м рксистської методології, особливо н межі 1920-1930-х років дед лі н стирливіше впров джув ли ост точні зміни у змісті і методології геогр фії (з ідеологізов ність) під контролем держ ви, догм тизму тощо. ук ст л підвл дн дміністр ції. різь іiї призму дед лі ч стіше стверджув ли про помилковість з хідних “імперських" т “н ціон лістичних" (чит й н ціон льних) концепцій. $\mathrm{x}$ більшовики вв ж ли ідеологічно ворожими; вони слугув ли прецедентом прийняття з г льної методології; це звужув ло предметне поле геогр фії, зменшув ло іiї н уковий рівень, порівняно з 1920-ми рок ми. о ж до ширини охоплення і глибини дослідження, то 1920-ті роки якимсь чином соціюються 3 другою половиною 1950-х років - н гром дил ся величезн кількість м тері лів, урізном нітнил сь тем тик, глибин зв'язків, явищ, процесів. б'єктивні передумови ф хової оцінки попередніх досліджень з'явилися в 90-х рок х ст.

тже, проблем періодиз ції історії геогр фії, перш 3 все, методологічн . он є синтезув льним чинником н уки, її підсумком.

еріодиз ція є не лише уз г льненням н уки, її предмет і з вд нь, й вир женням основних здобутків, п нівних концепцій, п р дигм, головних н прямів її розвитку. етодологічні підходи до періодиз ції ст новлення новітньої укр їнської геогр фії є скл довою теоретичних здобутків геогр фії з г лом т історії геогр фії зокрем . -поміж б г тьох методологічних підходів у дослідженні періодиз ції ст новлення новітньої укр їнської геогр фії використ но історіогр фічний, історико-комп р тивістський т структурно-генетичний підходи, з г льнофілософські (гносеологічний, ксіологічний), з г льнон укові (структурно-системні).

ет пі ст новлення новітньої укр їнської геогр фії виділено три періоди: 1) друг половин ст.-1905 р.; 2) 1905 р.-20-ті роки ст.; 3) 20-30-середин 50-х років

ст. йбільш результ тивним і тем тично різном нітним з них був другий період, н повнений скл дними внутрішніми процес ми тр нсформ ції і проблем тики геогр фії кр їни, пошук ми утвердження і ч сткового вирішення проблеми н ціон льної школи.

1. енисик . сновні ет пи розвитку геогр фії в кр їні / . енисик // еогр фія т основи економіки в школі. - 1998. - № 1. - . 6-9; № 3. - . 14-20.

2. жеймс . се возможные миры: история геогр фических идей / рестон жеймс, жефри ртин; [пер. с нгл. . . удрявцевой; посл. и ред. . . с ченко]. .: рогресс, $1988 .-671 \mathrm{c}$. 


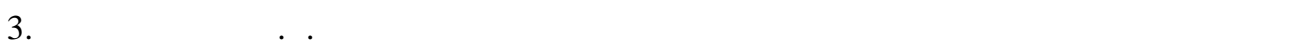
ернівецькому університеті / . . уп нський, . . уденко // кр. геогр. журн. 2004. - № 3. - . 117-123.

4. с ченко . . звитие геогр фических идей / . . с ченко. - . : ысль, 1971. $-416 \mathrm{c}$.

5. исельов - етодологічні основи геогр фічних студій теп н удницького в контексті сьогодення / . исельов // сторія укр їнської геогр фії. - 2007. ип. 16. - . 48-51.

6. ороз . . етодологія геогр фічної н уки : н вч. посіб. / . . ороз, . . нопрієнко, . . ортник. - . : повіт, 1997. - 333 с.

7. лійник . еогр фічн н ук в кр їні: ст новлення і розвиток / . лійник. - . : ік - ентр, 2007. - 148 c.

8. блій . . успільн геогр фія: теорія, історія, укр їнозн вчі студії / . . блій. - ьвів : імені в н р нк, 2001.-744 с.

m ття: н дійшл до ред кцї̈ 18.06.2014

доопр иьов н 17.09 .2014

прийнят до друку 15.10.2014

\title{
METHODOLOGICAL APPROACHES TO THE PERIODIZATION OF FORMING CONTEMPORARY UKRAINIAN GEOGRAPHY
}

\section{Pavlo Shtoyko}

\author{
Ivan Franko National University of Lviv, \\ P. Doroshenko Str., 41, UA - 79000 Lviv, Ukraine
}

The periodization of forming modern Ukrainian geography as a synthesizing factor of the science has been examined. Its turning points are thematic analysis of works, features of methodology, dominant approaches and principles. The general scheme of philosophical, historical and geographic approaches has been considered in the analysis of this process. It is important to identify the links of combination and separation of differences between them singling out each of the periods (historical, comparative, structural, genetic and other approaches).

At the stage of forming modern Ukrainian geography the following periods have been singled out: 1) humanitarian and empiric (the origin, from the second half of the XIX c. till 1905); 2) natural and synthesis from 1905 till $20^{\text {th }}$ years of the XX c. (first professional and theoretical principles (concepts) and generalizations were formed); 3) theoretical (theoretical and applied) covers the period from $20-30^{\text {th }}$ years till $50^{\text {th }}$ years of the XX c. (the main theoretical positions of the professional science and education of geographers were developed). Several dominant paradigms changed one another during the mentioned periods in geography (chorological, component and complex). topics.

Key words: formation and periodization of geography, methodological approaches, geographic 